\title{
A Missing Link: K-4 Biological Evolution Content Standards
}

\author{
Ron Wagler
}

Published online: 29 June 2010

(C) Springer Science+Business Media, LLC 2010

\begin{abstract}
The National Science Education Standards (NSES) is one of the most influential documents in US science education. The NSES has been utilized by local schools and districts, state departments of education, and national curriculum groups to form the backbone for curriculum frameworks, programs, and assessment systems to guide science education. The NSES provides national biological evolution content standards for fifth grade through high school but not for kindergarten through fourth grade. This article presents K-4 biological evolution content standards that can be used in conjunction with the current NSES K-4 life science and earth science content standards, brief examples of integration activities using the K-4 biological evolution content standards, and supplemental teacher information for the K-4 biological evolution content standards. The biological evolution content standards and the additional materials can guide teachers when teaching biological evolution to K-4th grade students.
\end{abstract}

Keywords Biological evolution · National Science Education Standards $\cdot$ K-4 $\cdot$ Content standards $\cdot$ Activities

\section{Introduction}

The National Science Education Standards (NSES) (NRC 1996) is one of the most influential documents in US science education. Since its construction over a decade ago, the NSES has been utilized by local schools and districts, state departments of education, and national curriculum

\section{R. Wagler $(\square)$}

Department of Teacher Education,

The University of Texas at El Paso,

500 West University Avenue, Education Building, Room 601,

El Paso, TX 79968-0574, USA

e-mail: rrwagler2@utep.edu groups "to form the backbone for curriculum frameworks, programs, and assessment systems to guide science education" (Carin et al. 2005, p. 14). ${ }^{1}$ The NSES continues to be a highly influential document that effectively informs and assists US science educators. Currently, the NSES provides biological evolution content standards for fifth grade through high school but not for kindergarten through fourth grade. A quality science education should expose students to biological evolution from kindergarten to high school. To assist in this endeavor, this article presents K-4 biological evolution content standards that can be used in conjunction with the current NSES K-4 life science and earth science content standards, brief examples of integration activities using the K-4 biological evolution content standards, and supplemental teacher information for the K-4 biological evolution content standards. The biological evolution content standards and the additional materials can guide teachers when teaching biological evolution to K-4th grade students.

\section{Biological Evolution's Centrality in a Quality K-12 Science Education}

Stephen Gould and Theodosius Dobzhansky were two of the greatest evolutionary biologists. Dobzhansky advocated "Nothing in biology makes sense except in the light of evolution" (Dobzhansky 1973, p. 125). Gould reaffirmed that "Evolution is not a peripheral subject but the central organizing principle of all biological science" (Gould 1999, p. 59). Countless other science and science education entities have similarly stated that the teaching of biological

\footnotetext{
${ }^{1}$ See Carin et al. 2005 for specific examples of the NSES influence on US science education.
} 
evolution is essential to a student's complete understanding of biology. These entities have included the National Association of Biology Teachers (NABT 2008), the American Association for the Advancement of Science (AAAS 1993, 2006; Rutherford and Ahlgren 1990), the National Academy of Sciences (NAS 1998), the National Science Teaching Association (NSTA 2003), the National Research Council (NRC 1996), and others.

As Dobzhansky and Gould have said, biological evolution is the central unifying theme of the biological sciences. Biological evolution is composed of processes and mechanisms that interact with abiotic and biotic components in the planet's biosphere. When biological evolution is not presented in the K-4th grade classroom along with the characteristics, life cycles, and the environments of organisms, the science curriculum is misrepresented and incomplete. The end result is fourth grade students who have no knowledge of biological evolution's interconnected relationship to the abiotic and biotic components of the earth. This lack of knowledge impacts a student's educational success when they are introduced, in their fifth to eighth grade life science courses, to the complex interactions of organisms and environments since biological evolution in an indivisible component of these interactions. ${ }^{2}$ As a result, the students overall long-term biological development (i.e., knowledge and application of that knowledge) is impacted by the lack of biological evolution knowledge that was not present in their K-4 educational experience.

\section{NSES K-12 Science Content Standards}

The NSES consists of science teaching standards, science teacher's professional development standards, assessment in science education standards, science content standards, science education program standards, and science education system standards. The science content standards (NRC 1996, p. 102-207) are not a science curriculum but a document that defines what science content should exist in the science curriculum at a particular grade level (K-4, 5-8 and 9-12) and in a specific science discipline (i.e., physical science, life science, earth and space science, etc.). Each specific science discipline is further broken down into specific science content sections.

The NSES K-4 life science content standards specific science content sections include the characteristics of organ-

\footnotetext{
$\overline{2}$ This scenario would not apply to students residing in states where biological evolution is not taught until high school (i.e., ninth to 12 th grade). In these students, their overall long-term biological development (i.e., knowledge and application of that knowledge) would be impacted by the lack of biological evolution knowledge that was not present in their K-8 educational experience.
}

isms, life cycles of organisms, and organisms and their environments. Biological evolution or specific biological evolution concepts are not mentioned in the NSES K-4 life science content standards or in any of the other NSES K-4 science content standards (NRC 1996, p. 121-141).

\section{K-4 Biological Evolution Content Standards}

The cognitive and conceptual abilities of students vary greatly from kindergarten to fourth grade and, as with the NSES K-4 science content standards, the K-4 biological evolution content standards (see Fig. 1) present the concepts and principles the students should develop an understanding of by the time they have completed fourth grade. The K-4 biological evolution content standards should be added to the NSES K-4 life science content standards and used in conjunction with the NSES K-4 life science (NRC 1996, p. 129) and earth science (p. 134, see fossil reference) content standards.

The K-4 biological evolution content standards have been constructed in a simple, narrative, "story-like" manner. Concepts from the current NSES K-4 life science and earth science content standards sections were used to construct the K-4 biological evolution content standards. These concepts included kind (i.e., kind of organism), organism (NRC 1996, p. 129), earth (p. 134), plant, animal (p. 129), lived long ago (p. 134), human, and fossil (p. 134). These concepts were used because they currently exist in the NSES K-4 life science and earth science content standards thereby reinforcing and integrating the K-4 biological evolution content standards to the current NSES K-4 life science and earth science content standards.

Fossils and what they can tell us about common ancestors and extinction were also used as a central theme in the construction of the K-4 biological evolution content standards. As before, the use of fossils links the current NSES K-4 life science and earth science content standards to the K-4 biological evolution content standards so students can understand the relationship that fossils have to biological evolution. These concepts were also incorporated into the K-4 biological evolution content standards to encourage the use of the NSES K-4 scientific inquiry standards in the K-4th grade classroom, specifically through the use of cognitively appropriate $\mathrm{K}-4$ th grade scientific inquiry activities that incorporate the use of fossils to increase student's biological evolution knowledge (NRC 1996).

These scientific inquiry activities, in the context of the $\mathrm{K}-4$ th grade classroom, begin in the early elementary classroom with scientific investigations that are largely focused on observations and then develop into scientific inquiry activities where only one variable at a time is changed (i.e., "fair" test; NRC 1996, p. 122). Scientific inquiry activities allow children to engage in "processes of science" 
Fig. 1 K-4 biological evolution content standards

\section{K-4 Biological Evolution Content Standards}

Directions: The K-4 Biological Evolution Content Standards should be added to the National Science Education Standards (NSES) K-4 Life Science Content Standards (p. 129) and used in conjunction with the NSES K-4 Life Science (p. 129) and Earth Science (p. 134, See fossil reference) Content Standards.

Biological Evolution of Organisms

- Many kinds of organisms have lived or are currently living on the earth. Most of these organisms (e.g., plants and animals) lived long ago and are now extinct.

- Organisms are related to one another by common ancestors that lived a long time ago. Fossils provide evidence that organisms have existed, that organisms of the same kind are related to one another by a common ancestor, have evolved and may or may not have become extinct.

- Organisms that are currently living on the earth are continuing to evolve. For example, different kinds of plants and animals are evolving, as are humans.
(NRC 1996, p. 105). These processes are "Ask a question about objects, organisms, and events in the environment; plan and conduct a simple investigation; employ simple equipment and tools to gather data and extend the senses; use data to construct a reasonable explanation; and communicate investigations and explanations" (NRC 1996, p. 122).

"It is important to remember these processes should not be interpreted as a rigid, step-by-step formula, or a single 'scientific method' that is used to solve a problem but rather common events that occur, in a logical sequence, within the context of a scientific inquiry classroom (NRC 1996). Just as scientific inquiry processes used in studies conducted by professional scientists takes on many forms, so too, the scientific studies children perform in their science classrooms should take on many forms" (Wagler 2010).

When the K-4 biological evolution content standards are applied to specific classroom activities, in some cases, the activities may focus on the changing of a population of organism's observable physical characteristics over time. Activities of this nature, when performed with older elementary students, present ideal opportunities to introduce the term "gene" and the relationship genes have to an organism's changing observable physical characteristics (i.e., genetic change in a population of organisms over time is biological evolution).

Examples of organisms, such as trilobites with their large exoskeletal diversity, provide good opportunities to discuss the role genes play in these evolutionary changes. See "Brief Examples of Integration Activities Using the K-4 Biological Evolution Content Standards" section for an example of trilobite activity and Fig. 2 for some introductory information on trilobites. Examples of non-observable physical characteristics can also be used that show humans are continuing to evolve (e.g., lactose tolerance). See the Further Reading at the end of this article for more information on human evolution. Both of these examples are an effective way to begin to introduce the genetic concepts students will encounter in grades five to eight (NRC 1996, p. 157).

Some may contend that young children are not cognitively ready, at the $\mathrm{K}-4$ th grade level, to learn about biological evolution. This may be because when the K-4 biological evolution content standards are applied to specific activities in the $\mathrm{K}-4$ th grade classroom, in some cases, these activities may require abstract thought on the part of the student. "Contrary to conceptions of development held 30 or 40 years ago, young children can think both concretely and abstractly" (NRC 2007, p. 3). The belief that elementary children have broad cognitive limitations is no longer embraced by the cognitive developmental research community (Carey 1985; Gelman and Baillargeon 1983; Gelman and Kalish 2005; Keil et al. 1998; Metz 1995; Toyama 2000).

"The notion of young children as hopelessly concrete and incapable of abstract thought is undermined by 
Fig. 2 Supplemental introductory teacher information for the K-4 biological evolution content standards. ${ }^{\mathrm{a}}$ Dates with the $\approx$ symbol may change as new scientific evidence is discovered. ${ }^{b}$ In the scientific community there is a debate as to the specific definition of this scientific term

\section{Supplemental Introductory Teacher Information for the K-4 Biological Evolution Content Standards}

The universe is approximately $\left(\approx^{\mathrm{a}}\right) 13.7$ billion years old. The earth is $\approx 4.5$ billion years old. The first living cells appeared between $\approx 3.8$ and 3.7 billion years ago (Bya). The oldest fossils, cyanobacteria-like cells called stromatolites, are $\approx 3.5$ billion years old. All organisms evolved from a single organism that lived $\approx 3.8-3.5$ Bya. $\approx 99 \%$ of all of the species that have ever existed on earth are extinct. Between $\approx 7$ and $\approx 100$ million living species currently exist on earth. Fossils provide scientific evidence that organisms have or have not become extinct, have evolved, and are related to one another by a common ancestor. For example, trilobites (See Figure 3) are marine invertebrates that are only known as fossils. There are $\approx 19,000$ known species of trilobites that lived from $\approx 540$ to 250 million years ago (Mya) as determined by the fossil record. Photographs and detailed information on trilobites can be found at www.trilobites.info. Because trilobites have a hard shell they are easily fossilized. Trilobite fossils are common. The fossils of trilobites provide scientific evidence that trilobites once existed. Trilobite fossils can be assigned a date. Radiometric dating is one way to assign a date to a fossil. Based on this dating technique and others humans know trilobites lived between $\approx 540$ to 250 Mya. The fact that humans do not find any living species of trilobites on the earth today provides further scientific evidence that all species of trilobites went exist $\approx 250$ Mya. By looking at the ages of different trilobite species and their changing characteristics over time ( $\approx 540$ to 250 Mya) humans conclude that trilobites evolved from a common ancestor and evolutionary processes and mechanisms (e.g., natural selection) produced new trilo bite species (See Figure 4 and 5). See the Further Biological Evolution Teaching Resources section for websites that will help you answer biological evolution questions your students may have.

\section{Glossary of Scientific Terms}

Biological Evolution: Genetic change in a population of organisms over time (Johnson, 2003).

Extinct: No longer living.

Fossil: Remains or traces of prehistoric organisms preserved in rocks (Monroe, et al., 2007).

Organism $^{\text {b}}$ : Living things that share five basic properties: composed of one or more cells, use energy, maintain stable internal conditions, reproduce and possess a genetic system that is based on deoxyribonucleic acid (DNA). Examples include plants, animals, fungi, protists, and bacteria (Johnson, 2003).

Natural Selection: The differential survival and reproduction of organisms whose genetic traits better adapt them to particular environments (Lewis et. al, 2002)

Sedimentary Rocks: Any rock composed of sediments (such as sandstone and limestone) (Monroe, et al., 2007).

Species ${ }^{\mathrm{b}}$ : A population or a group of populations, whose members can interbreed and produce fertile offspring (Lewis et. al, 2002). This definition does not apply to asexual organisms. their early emerging abilities to track all sorts of highly abstract relations in the world around them. They have rich knowledge of natural phenomena. They are able to reason in ways that provide a foundation for scientific thinking, including potential precursors of modeling, designing experiments, and reasoning about theory and evidence. They also enter school with a broad and impressive set of knowledge skills that allow them to use and work with knowledge in sophisticated ways, although they may lack a clear sense of what is unique about science" (NRC 2007, p. 81).

\section{Brief Examples of Integration Activities Using the K-4 Biological Evolution Content Standards}

Because the K-4 biological evolution content standards were constructed in a simple, narrative, "story-like" manner, they can easily be added to existing K-4th grade science curriculums and be integrated across the entire K-4th grade curriculum. For example, an inquiry-based science activity on biological evolution can be integrated with art by allowing students to make trilobite fossils and evolutionary tree posters (see Figs. 2, 3, 4, and 5). The activity would begin by having students look at pictures showing the great exoskeletal diversity of different kinds (i.e., species) of trilobite fossils over time, make an initial trilobite fossil out of clay, modify their trilobite fossil's exoskeleton, and then speculate as to why this evolutionary modification helps, hinders, or has no impact on the animal in its environment. The clay fossils can then be used to discuss fossil formation and finally integrated with an evolutionary tree poster activity (see Fig. 4).

Even though the diagram presented in Fig. 4 is of trilobites, students can make evolutionary tree posters of many different groups of animals (or plants) that are evolutionarily related. Instead of using a line diagram, they can draw an actual tree with the common ancestor of all the 
organisms at the tree's base. ${ }^{3}$ Case in point, multiple classes can make posters (poster board size or larger) that show how fish, amphibians, reptiles, birds, and mammals (all vertebrates) are evolutionarily related and share a common ancestor. Extinct groups of animals can also be added to the posters. These large evolutionary "tree" posters can then be enhanced by allowing students to draw representative animals from each of the groups (e.g., amphibians: salamander) and attaching them to the proper "tree" branch on the poster. Each class's poster would be unique because of the type of tree they chose and the animal drawings they included. Finally, these posters can be displayed in the student's classrooms, other areas of the school, and at school events.

A mathematics unit can be integrated with reading, writing, and science by allowing students to read stories on dinosaurs, make trace fossils using toy dinosaurs and clay, write about dinosaur biological evolution, and calculate, using addition or subtraction, when specific dinosaurs emerged, how long they evolved, and when they went extinct. These large expanses of time can be grasped by allowing students to measure geological time by making a visual representation with string (e.g., one millimeter equals a certain number of years). These strings can then be compared to shorter strings (e.g., the age of an individual they know). This allows the student to take the abstract concept of large expanses of geological time and visually contrast it to the concrete real-world concept of an individual's age they know.

This unit can further be integrated into a scientific inquiry, environmental education biodiversity activity addressing how anthropogenic (i.e., human) events such as habitat modification, fragmentation and destruction are impacting global non-extinct avian dinosaurs (i.e., birds). For more detailed examples of biological evolution activities that can be performed with K-4 students, see the articles "Teaching Evolution in Primary Schools: An Example in French Classrooms" and "Teaching Evolution Concepts to Early Elementary School Students" and the "Understanding Evolution" website in the Further Reading at the end of this article.

\section{Supplemental Introductory Teacher Information for the K-4 Biological Evolution Content Standards}

Supplemental introductory teacher information for the K-4 biological evolution content standards is provided for K-4th grade teachers (see Figs. 2, 3, 4, and 5). This introductory information is presented to assist the K-4th grade teacher in beginning to understand some of the higher level concepts

\footnotetext{
${ }^{3}$ When performing this activity with K-4th grade students, do not include a time scale.
}

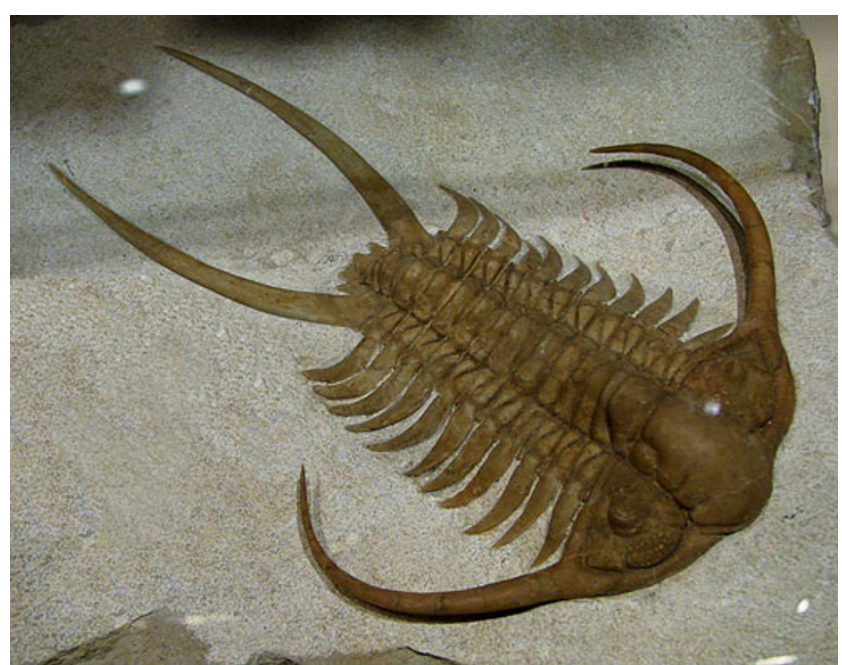

Fig. 3 A fossil of one of the approximately 19,000 extinct species of trilobites. Permission has been granted to use this image from the copyright holder. Source: http://en.wikipedia.org/wiki/File:Trilobite_ Ordovicien_8127.jpg

underpinning the K-4 biological evolution content standards and how the teacher can better prepare their students for the biological evolution concepts they will encounter in fifth to eighth grade. This introductory information also begins to provide the K-4th grade teacher with a biological evolution knowledge base that can increase the teacher's overall confidence and abilities when answering inquisitive student's questions, which will arise, when teaching biological evolution to K-4th grade students. Since the material present in Figs. 2, 3, 4, and 5 is only introductory in nature, it is recommended that the $\mathrm{K}-4$ th grade teachers explore the Further Reading in order to expand their biological evolution knowledge and pedagogy skills.

Figure 4 presents a diagram of simplified trilobite biological evolution showing how more recent species of trilobites evolved from older species of trilobites. Speciation is an evolutionary process whereby new species arise. Note that the common ancestor of all trilobites occurs at $\approx 540$ million years ago, and by $\approx 250$ million years ago, all trilobite species are extinct.

Figure 5 presents a diagram of simplified common ancestry, speciation, and extinction among trilobite groups. Begin with the common ancestor of all trilobites at $\approx 540$ million years ago and follow the lines through time to $\approx 250$ million years ago. Whenever a line branches, speciation occurs and two new trilobite groups arise. These two new trilobite groups share a common ancestor at the point where the two lines branch. All of the trilobite groups present in the diagram are related to the common ancestor of all trilobites. When a line ends, a trilobite group has gone extinct. Note that by $\approx 250$ million years ago, all trilobite species are extinct. 
Fig. 4 A diagram of simplified trilobite biological evolution

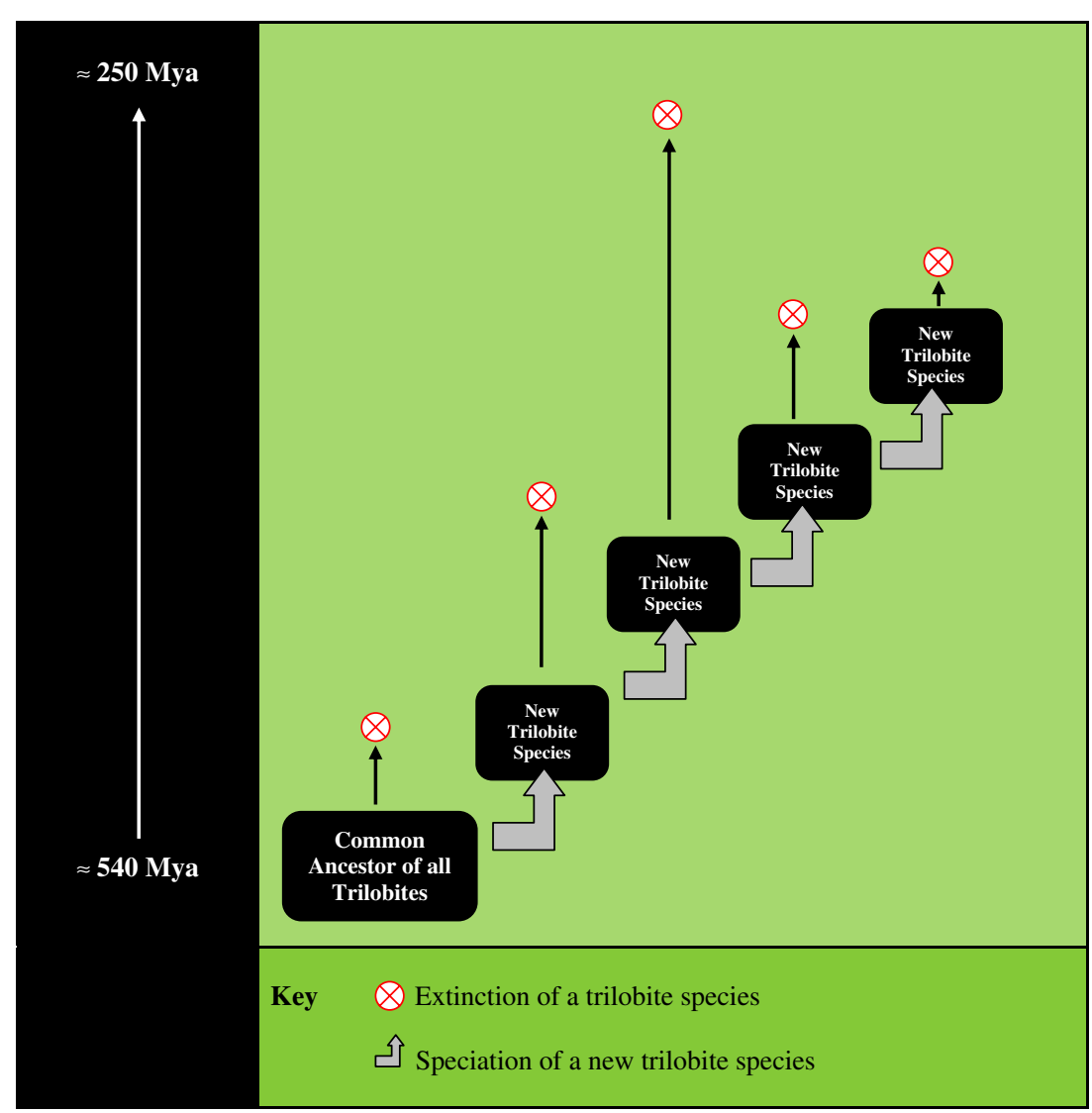

Fig. 5 A diagram of simplified common ancestry, speciation, and extinction among trilobite groups

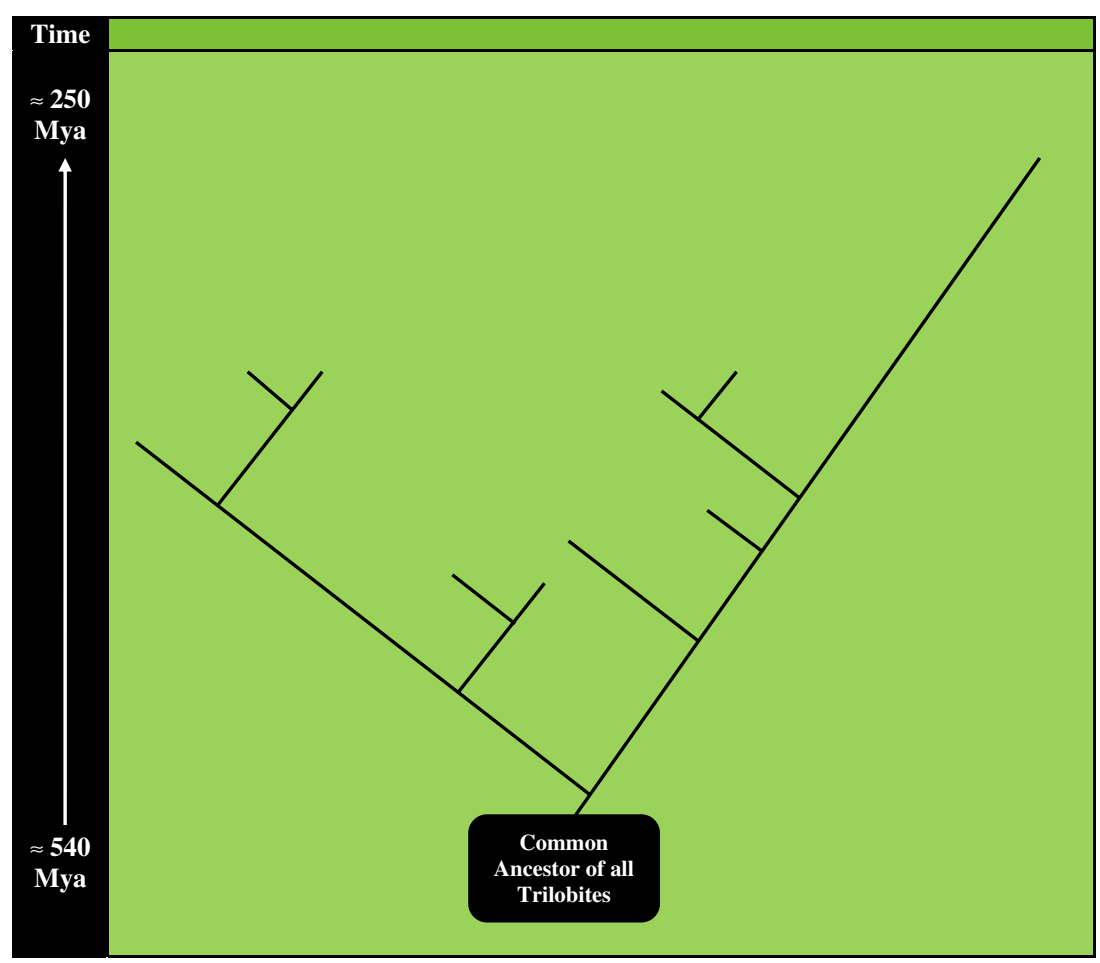




\section{Conclusion}

A quality science education should expose students to biological evolution from kindergarten to high school. The K-4 biological evolution content standards are one tool that can make this vision a reality by guiding and assisting teachers when they teach biological evolution to K-4th grade students. They also provide an essential foundational knowledge base for future complex biological, evolutionary, geological, and ecological concepts students may encounter in their educational career such as the biodiversity of extinct and extant organisms, genetic drift, gene flow, biological coevolution, mutation, the Last Universal Common Ancestor (Glansdorff et al. 2008; Woese 1998), the geological time scale, mechanisms and processes of extinction, the past five great mass extinctions (Erwin 2001; Jablonski 1995), the current sixth mass extinction (Wake and Vredenburg 2008; Jackson 2008; Parry et al. 2007; Lewis 2005; Thomas et al. 2004; McDaniel and Borton 2002; Myers et al. 2000), and many more. Beyond this, they also provide a set of content standards that can offer students, from kindergarten to high school, a complete and accurate picture of the biological sciences. As Theodosius Dobzhansky once wrote, "Seen in the light of evolution, biology is, perhaps, intellectually the most satisfying and inspiring science. Without that light it becomes a pile of sundry facts-some of them interesting or curious but making no meaningful picture as a whole" (Dobzhansky 1973, p. 129).

\section{References}

American Association for the Advancement of Science (AAAS). Benchmarks for science literacy. New York: Oxford University Press; 1993.

American Association for the Advancement of Science (AAAS). AAAS statement on the teaching of evolution. 2006. Retrieved April 30, 2009 from http://www.aaas.org/news/releases/2006/pdf/ 0219boardstatement.pdf.

Carey S. Conceptual change in childhood. Cambridge: MIT; 1985.

Carin AA, Bass JE, Contant TL. Teaching science as inquiry. Upper Saddle River: Pearson Merrill Prentice Hall; 2005.

Dobzhansky T. Nothing in biology makes sense except in the light of evolution. Am Biol Teach. 1973;35:125-9.

Erwin DH. Lessons from the past: biotic recoveries from mass extinctions. Proc Natl Acad Sci. 2001;98:1399-403.

Gelman R, Baillargeon R. A review of some Piagetian concepts. In: Flavell JH, Markman EM, editors. Handbook of child psychology, vol. 3. Hoboken: Wiley; 1983. p. 167-230.

Gelman S, Kalish C. Conceptual development. In: Siegler RS, Kuhn D, editors. Handbook of child psychology volume 2, cognition, perception, and language. 6th ed. Hoboken: Wiley; 2005. p. 687-733.

Glansdorff N, Xu Y, Labedan B. The last universal common ancestor: emergence, constitution and genetic legacy of an elusive forerunner. Biol Direct. 2008;3:29.

Gould SJ. Dorothy, it's really oz. A pro-creationist decision in Kansas is more than a blow against Darwin. Time Mag. 1999;154:59.
Jablonski D. In: May RM, Lawton JH, editors. Extinction rates. Oxford: Oxford University Press; 1995. p. 25-44.

Jackson JBC. Ecological extinction and evolution in the brave new ocean. Proc Natl Acad Sci. 2008;105:11458-65.

Johnson GB. The living world. New York: McGraw Hill; 2003.

Keil FC, Smith CS, Simons D, Levin D. Two dogmas of conceptual empiricism. Cognition. 1998;65:103-35.

Lewis SL. Tropical forests and the changing earth system. Philos Trans R Soc B. 2005;361:195-210.

Lewis R, Gaffin D, Hoefnagels M, Parker B. Life. New York: McGraw Hill; 2002.

McDaniel CN, Borton DN. Increased human energy use causes biological diversity loss and undermines prospects for sustainability. Bioscience. 2002;52(10):926-36.

Metz KE. Reassessment of developmental constraints on children's science instruction. Rev Educ Res. 1995;65:93-127.

Monroe JS, Wicander R, Hazlett R. Physical geology: exploring the earth. Belmont: Thomson Brooks/Cole; 2007.

Myers N, Mittermeier RA, Mittermeier CG, da Fonseca GAB, Kent J. Biodiversity hotspots for conservation priorities. Nature. 2000;403:853-8.

National Association of Biology Teachers (NABT). NABT's statement on teaching evolution. 2008. Retrieved on April 30, 2009 from http://www.nabt.org/websites/institution/index.php?p=92.

National Academy of Sciences (NAS). Teaching about evolution and the nature of science. Washington: National Academy; 1998.

National Research Council (NRC). National Science Education Standards. Washington: National Academy; 1996.

National Research Council (NRC). Taking science to school: learning and teaching science in grades K-8. Washington: National Academies; 2007.

National Science Teachers Association (NSTA). NSTA position statement: The teaching of evolution. 2003. Retrieved on May 12, 2009 from http://www.nsta.org/about/positions/evolution.aspx

Parry ML, Canziani O, Palutikof J, van der Linden P, Hanson C, editors. Climate change 2007: impacts, adaptations and vulnerabilities (contribution of working group II to the fourth assessment report of the Intergovernmental Panel On Climate Change). Cambridge: Cambridge University Press; 2007.

Rutherford FJ, Ahlgren A. Science for all Americans. New York: Oxford University Press; 1990.

Thomas CD, Cameron A, Green RE, Bakkenes M, Beaumont LJ, Collingham $\mathrm{YC}$, et al. Extinction risk from climate change. Nature. 2004; 427:145-8.

Toyama N. What are food and air like inside our bodies? Children's thinking about digestion and respiration. Int $\mathrm{J}$ Behav Dev. 2000;24(2):222-30.

Wagler R. Using science teaching case narratives to evaluate the level of acceptance of scientific inquiry teaching in preservice elementary teachers. J Sci Teach Educ. 2010;21(2):215-26. doi:10.1007/s10972-009-9160-9.

Wake DB, Vredenburg VT. Are we in the midst of the sixth mass extinction? A view from the world of amphibians. Proc Natl Acad Sci. 2008;105:11466-73.

Woese C. The universal ancestor. Proc Natl Acad Sci. 1998;95 (12):6854-9.

\section{Further Biological Evolution Teaching Resources}

Chanet B, Lusignan F. Teaching evolution in primary schools: an example in French classrooms. Evo Edu Outreach. 2009;2:13640. Available online at http://www.springerlink.com/content/ c0gj785386840868/. 
Nadelson L, Culp R, Bunn S, Burkhart R, Shetlar R, Nixon K, et al. Teaching evolution concepts to early elementary school students. Evo Edu Outreach. 2009;2:458-73.

National Science Teachers Association (NSTA). Evolution Resources http://www.nsta.org/publications/evolution.aspx. This website provides many diverse biological evolution teaching resources.

Understanding Evolution. http://evolution.berkeley.edu/. This website is unique in that it provides biological evolution resources that are appropriate for the K-4 classroom. For K-4 teachers needing to increase their knowledge of biological evolution (e.g., natural selection), so you can answer biological evolution questions your students may have, there are online tutorials to assist teachers in understanding what biological evolution is and how it works. There are also biological evolution lesson plans for grades K-4 and answers to possible questions your students may ask. 